\title{
PHYSIOLOGICAL STUDIES ON THE EFFECTS OF HORMONAL IMBALANCE ON THE CENTRAL NERVOUS SYSTEM
}

\section{Effects of Hypophysectomy on Certain Biochemical Parameters in the Brain of Frog}

By S. Suryaprabha and Kandula Pampapathi Rao

(Department of Zoology, Bangalore University, Bangalore-1)

Received February 28, 1973

\begin{abstract}
The acetylcholinesterase activity, RNA levels, total free amino acids and magnesium content in fore-, mid- and hind-brain were determined in the normal and hypophysectomised frogs (Rana cyanophlyctus). Hypophysectomy results in a marked decrease in the free $a-a$ and in Mg. RNA also decreases significantly, but not to the same degree as the $a-a$ and Mg. But AchE levels do not change significantly although there is a general decrease. It is suggested that the decrease in $\mathrm{Mg}$ is a reflection of the ionic imbalance resulting from hormonal imbalance. Hypophysectomy also results in reduced protein synthesis (and/or turnover) in the CNS as indicated by reduced RNA and $a-a$.
\end{abstract}

\section{INT RODUCTION}

THE pituitary gland has been shown to be a very important chemical co-ordinator of several metabolic and physiological functions in the vertebrates (Turner, 1966). It is now becoming increasingly clear that the other major co-ordinating and integrating system in the vertebrates, namely the Central Nervous System (CNS), is greatly influenced by the levels of certain chemicals and hormones in the blood and it is becoming evident that such effects on the CNS determine several functions which are dependent upon the CNS for expression. In view of the great importance of the pituitary, considerable amount of experimental work has been done and continues to be done using hypophysectomised vertebrates. Such hypophysectomised animals experience conspicuous alterations in their blood chemistry especially with regard to the levels of hormones circulating in the blood. Therefore it would be obvious that these changes 
in the blood level of hormones in such animals would have very important effects on the metabolism and activity of the CNS. However, little information has so far been gathered on such changes in the CNS in hypophysectomised animals.

There are some studies on the effects of certain hormones, especially of the thyroid hormone and some of the sex hormones, on the biochemistry and physiology of the CNS in the rat.

Thyroidectomy has been shown to result in a decrease in total cholinesterase activity in the brain of the rat (Hamburgh and Flexner, 1967). Likewise neonatal hypothyroidism results in a depression of the ATPase activity in cortical tissue in rat (Valcana and Timiras, 1969) and also decreases cortical RNA levels (Geel and Timiras, 1967). Hypothyroidism is known to alter the levels of glutamate decarboxylase (Balazs, Kovacs et al., 1968) and GABA transaminase (Garcia Argiz et al., 1967), while it also results in a decrease in protein synthesis. In Amphibia it has been shown that thyroid hormone has significant effect upon the aifferentiation of certain neuronal units (Kollros, 1968).

There is also some published evidence which shows that gonadal steroids ate involved in the modification of the central nervous activity and function (Woodbury and Vernadakis, 1966; Vernadakis and Timiras, 1966). Specificity of hormonal action on discrete areas of the brain (Timiras, Vernadakis and Sherwood, 1968) and specific areas of the brain selectively concentrating estradiol (Woolley, Holinka and Timiras, 1969) have also been reported. Effects of growth hormone $(\mathrm{GH})$ on the CNS resulting in an increase in brain DNA content have been reported (Zamenhof, Mosely and Schuller, 1966).

In the light of the relatively scant information available in this regard and in view of the common usage of frog and other amphibians in the laboratory for experimental purposes and in view of the great need for an understanding of the effects of hormonal imbalance on the physiological state of the CNS, the present study has been undertaken.

An attempt is made to measure changes in a few important metabolic parameters such as the RNA levels and the amino acid content. Further in important ion such as magnesium and a neuropharmacologically important constituent such as the acetylcholinesterase content have also been studied in the three major parts of the brain of frog. 


\section{MATERIAL AND MethodS}

The commonly occurring frog, Rana cyanophlyctus, has been used in this study. The frogs were maintained in glass aquaria at laboratory temperature which varied around $25^{\circ} \mathrm{C}$. The frogs were force-fed once every three days with frog muscle. In all cases the brain was dissected out from the ventral aspect and immediately used for analysis. The fore-brain, midbrain and hind-brain were taken separately for purposes of analysis.

For hypophysectomy the animals were anaesthetized and were then operated. After hypophysectomy individual frogs were maintained in aquaria upto 7 days before they were sacrificed. The hypophysectomised animals were given injections of $1 \% \mathrm{NaCl}$ solution daily and were also forcefed as mentioned above.

The known weight of each part of the brain from the normal and the hypophysectomised individuals were analysed for the RNA, amino acids, magnesium and acetylcholine contents as follows:

RNA was determined by the orcinol colour reagent method (SchmidtSchneider, 1946) where the tissue was homogenised with methanol and then treated with TCA, ethanol-ether, PCA and orcinol in step-wise reactions to remove traces of other components so as to leave only RNA. The optical density was read at $720 \mathrm{~m} \mu$.

Amino acids were determined by the photometric method (Folin and Danielson, 1933) from the colour developed by the reaction between the amino acids and naphthoquinone 4 sulphonic acid in alkaline solution, which is the basis of the method. The optical density was read at $490 \mathrm{~m} \mu$. Magnesium was determined by the Milton and Waters method, wherein magnesium was precipitated as magnesium ammonium phosphate and the latter was estimated by colorimetric phosphate determination as described in Milton and Waters. ${ }^{19}$

Acetylcholine esterase was determined by Hestrin's method (1949) which is based upon the disappearance of acetylcholine as determined by the ferric-acetyl droxamic acid complex where one unit is equivalent to the disappearance of one micromole of acetylcholine per minute at $25^{\circ} \mathrm{C}$.

\section{RESULTS}

The data obtained is summarised in Table I. It is seen from this table that hypophysectomy results in very marked decrease in the levels of free 


\section{TABLE I}

Comparison of the different constituents measured in the different parts of the brain of normal and hypophysectomised frogs

\begin{tabular}{|c|c|c|c|c|c|c|}
\hline & \multicolumn{2}{|c|}{ Fore-brain } & \multicolumn{2}{|c|}{ Mid-brain } & \multicolumn{2}{|c|}{ Hind-brain } \\
\hline & Normal & Hypo & Norinal & Hypo & Normal & $\mathrm{H}_{\zeta}$ po \\
\hline \multirow{2}{*}{ Amino acids $\mu \mathrm{gm} / \mathrm{Mg}$} & $\begin{array}{c}6 \cdot 018 \pm 1 \cdot 6 \\
(5)\end{array}$ & $\begin{array}{c}1 \cdot 68 \pm 0.25 \\
(6)\end{array}$ & $4 \cdot 81 \underset{(5)}{ \pm} 1 \cdot 04$ & $\begin{array}{c}2.52 \pm 0.14 \\
(6)\end{array}$ & $\frac{5 \cdot 35 \pm}{(5)} 1 \cdot 7$ & $\begin{array}{c}2 \cdot 92 \pm 0 \\
(6)\end{array}$ \\
\hline & \multicolumn{2}{|c|}{$\begin{array}{c}t=5.81 \quad \mathrm{P}>0.005 \\
\text { V. Sign. }\end{array}$} & \multicolumn{2}{|c|}{$\begin{array}{c}t=4.83 \quad \mathrm{P}>0.005 \\
\text { V. Sign. }\end{array}$} & \multicolumn{2}{|c|}{$\begin{aligned} t=2.73 \quad \mathrm{P} & >0.025 \\
& <0.01 \\
\text { Sign. } & \end{aligned}$} \\
\hline \multirow{2}{*}{ RNA $\mu g \mathrm{~m} / \mathrm{Mg}$} & $\begin{array}{c}78 \cdot 18+13 \cdot 6 \\
(6)\end{array}$ & $\frac{46 \cdot 15 \pm 3 \cdot 82}{(5)}$ & $66 \cdot 6 \pm \frac{7 \cdot 5}{(6)}$ & $\underset{(5)}{46 \cdot 3 \underset{(5 \cdot 9}{7 \cdot 9}}$ & $\begin{array}{c}84 \cdot 97 \pm 15 \cdot 3 \\
(6)\end{array}$ & $45 \cdot 6 \underset{(5)}{ \pm} 3 \cdot$ \\
\hline & \multicolumn{2}{|c|}{$t=4.6 \underset{\text { V. }}{\mathrm{Sign} .}$} & \multicolumn{2}{|c|}{$\begin{array}{c}t=3.9 \quad \mathrm{P}>0.005 \\
\text { V. Sign. }\end{array}$} & \multicolumn{2}{|c|}{$\begin{array}{c}t=4 \cdot 3 . \\
\text { V. Sign. }\end{array}$} \\
\hline \multirow{2}{*}{ Magnesium $\mu \mathrm{gm} / \mathrm{Gm}$} & 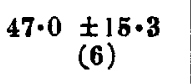 & $12 \underset{(5)}{ \pm 10 \cdot 6}$ & $54 \quad \begin{array}{l} \pm 26.99 \\
(6)\end{array}$ & $15 \underset{(5)}{ \pm} 5 \cdot 2$ & $35 \quad \begin{array}{l} \pm 14 \cdot 0 \\
(6)\end{array}$ & $19 \underset{(5)}{ \pm 6}$ \\
\hline & \multicolumn{2}{|c|}{$\begin{array}{c}t=3.504 \quad \mathrm{P}>0.005 \\
\text { V. Sign. }\end{array}$} & \multicolumn{2}{|c|}{$\begin{array}{c}t=5.72 \quad P>0.005 \\
\text { V. Sign. }\end{array}$} & \multicolumn{2}{|c|}{$\begin{array}{cc}t=1.902 & P \geq .05 \\
\text { Sign } & \gtrless .025\end{array}$} \\
\hline \multirow{2}{*}{ AChE Unit/Mg protein } & $\begin{array}{c}6.98 \pm 0.26 \\
(6)\end{array}$ & $\begin{array}{c}6.02 \pm 0.52 \\
(5)\end{array}$ & $5 \cdot 2 \underset{(6)}{ \pm 0 \cdot 10}$ & $4 \cdot 7 \underset{(5)}{ \pm} \cdot 78$ & $4 \cdot 7 \pm 0.15$ & $4 \cdot 06 \pm 0$. \\
\hline & $\begin{array}{r}t=2 \cdot 73 \\
\mathrm{Siq}\end{array}$ & $\begin{array}{l}P \geq .025 \\
<.01 \\
n .\end{array}$ & \multicolumn{2}{|c|}{$\begin{array}{c}t=1.6 \quad \mathrm{P}>\cdot 1 \\
\quad<\cdot 05 \\
\text { F. Sign. }\end{array}$} & \multicolumn{2}{|c|}{$\begin{aligned} t=2.914 \quad \mathrm{P} & \geq .01 \\
\text { Sign. } & <.005\end{aligned}$} \\
\hline
\end{tabular}

amino acids in all the three different parts of the brain, although the decrease is most conspicuous percentage-wise in the fore-brain. Likewise there is an equally marked decrease in the total magnesium content in all the three parts of the brain in hypophysectomised frogs. Here again the decrease is most conspicuous percentage-wise in the fore-brain while the mid-brain also exhibits a nearly similar drop. With regard to RNA levels, while a significant decrease is noticed in all the three parts of the brain after hypophysectomy the degree to which the change has occurred is not as great as in the other two parameters mentioned above. Further, the relative change in the 
different parts of the brain is nearly the same although the hind-brain seems to be the most affected unlike in the case of the amino acids and magnesium mentioned above.

On the other hand, it is quite noteworthy that the AchE content does not change very significantly after hypophysectomy although there is a general decrease in total AchE content in all the three parts of the brain. In fact here again the change seems to be most marked in the hind-brain rather than in the fore-brain.

Comparing the different parts of the brain it could be seen that even in the normal animals, there are significant differences between the different parts of the brain in the level of occurrence of at least some of the constituents measured (Table II). Thus for example it may be seen that there are considerable differences betwen the mid-brain and the other two parts of the brain in the level of occur, ence of RNA, the mid-brain having the lowest RNA content. Likewise, significant differences are noticed in the AchE content of different parts of the normal brain. However, here the hindbrain shows the lowest values while the forebrain the highest. On the other hand there do not appear to be any significant differences between the different parts of the normal brain in the occurrence of free amino acids and to a great extent in the level of magnesium. However, the magnesium content is lowest in the hind-brain and this is fairly significantly different from the magnesium content in the mid-brain where it is highest.

Instituting a similar comparison between the different parts of the brain in the hypophysectomised frogs (Table III) it could be seen that some of the differences noticed above in the normal animals are abolished. Thus for example it is noticed that the RNA content drops to a uniformly low level in all the three different parts of the brain after hypophysectomy. Likewise the AchE content also decreases to a nearly uniform level in the different parts of the brain, although still the difference between the fore-brain and hind-brain tends to be fairly significant. Although there is a remarkable decrease in the magnesium content after hypophysectomy the decrease is uniformly great in the three differnt parts of the brain and therefore the different parts of the brain show similarly low values, hence the differences between the different parts of the brain continue to be not significant. With regard to the amino acid content although there has been a considerable decrease after hypophysectomy such decrease was not uniform in the different parts of the brain and therefore the different parts of the brain in the hypophysectomised animals continue to be significantly different in the 
TABLE II

The biochemical contents as compared between the different parts of the brain of the normal frog

\begin{tabular}{|c|c|c|c|c|c|c|}
\hline & Fore-brain & Mid brain & Ilind-brain & Mid-brain & Fore-brain & Hincl-brain \\
\hline \multirow{3}{*}{ Amino acids $\mu_{\mathrm{gm}} / \mathrm{Mg}$} & $6 \cdot 02 \pm 1 \cdot 63$ & $4.81 \pm 1.04$ & $5 \cdot 34 \pm 1 \cdot 7$ & $4 \cdot 81 \pm 1 \cdot 04$ & $6.02+1.63$ & $5 \cdot 34+1 \cdot 7$ \\
\hline & \multicolumn{2}{|c|}{$\begin{array}{c}t=1.25 \quad \mathrm{P} \geq .15 \\
\text { Insign. }\end{array}$} & \multicolumn{2}{|c|}{$\begin{array}{c}t=0.54 \quad P>.35 \\
\text { Insign. }\end{array}$} & \multicolumn{2}{|c|}{$\begin{array}{c}t=0.59 \quad \mathrm{P}>0.5 \\
\text { Insign. }\end{array}$} \\
\hline & Fore brain & Mid-brain & Hind brain & Mid-brain & llind-brain & Fore-brain \\
\hline \multirow{3}{*}{$\mathrm{KNA} \quad \mu g m / M_{g}$} & $78 \cdot 18 \pm 13 \cdot 6$ & $66 \cdot 6 \pm 7 \cdot 5$ & $84 \cdot 97 \pm 15 \cdot 3$ & $66.6 \pm 7.5$ & $84 \cdot 97 \pm 15 \cdot 3$ & $78 \cdot 2 \pm 13 \cdot 6$ \\
\hline & \multicolumn{2}{|c|}{$\begin{array}{c}t=1.67 \quad \mathrm{P}>0.01 \\
<0.05 \\
\text { Sign. }\end{array}$} & \multicolumn{2}{|c|}{$\begin{aligned} t=2.414 \quad \mathrm{P} & >0.025 \\
\text { Sign. } & <.01\end{aligned}$} & \multicolumn{2}{|c|}{$\begin{array}{cc}t=0.7605 \quad \mathrm{P} & <.25 \\
& <.2 \\
\text { Insign. } & \end{array}$} \\
\hline & Mid-brain & Fore-brain & Mid-brain & Hind-brain & Fore-brain & Hind-brain \\
\hline \multirow{3}{*}{ Magnesium $\mu \mathrm{gm} / \mathrm{Gm}$} & $53 \cdot 8 \pm 26.9$ & $47 \cdot 0 \pm 16 \cdot 3$ & $63 \cdot 8 \pm 26 \cdot 9$ & $\therefore 5 \pm 14$ & $47 \pm 15 \cdot 3$ & $35 \pm 14$ \\
\hline & \multicolumn{2}{|c|}{$\begin{array}{c}t=.48 \quad \mathrm{P}>.35 \\
<.3 \\
\text { Insign. }\end{array}$} & \multicolumn{2}{|c|}{$\begin{array}{c}t=1.4 \quad \mathrm{P}_{\geq}^{<.1} \\
\text { F. Sign. }\end{array}$} & \multicolumn{2}{|c|}{$\begin{array}{c}t=1 \cdot 3 \quad \mathrm{P}>\cdot 15 \\
\text { Insign. }\end{array}$} \\
\hline & Fore-brain & Mid-brain & Mid-brain & Hind brain & Fore-brain & Hind-brain \\
\hline \multirow[b]{2}{*}{ AChE Units/Mg protein } & $6.98 \pm 0.26$ & $5 \cdot 2 \pm \cdot 10$ & $5 \cdot 2 \pm \cdot 10$ & $4 \cdot 7 \pm \cdot 14$ & $6.98 \pm \quad .26$ & $4 \cdot 7 \pm \cdot 4$ \\
\hline & $\begin{aligned} t=1 \cdot 44 \\
\text { F. Si }\end{aligned}$ & $\begin{aligned} P & >\cdot 1 \\
& <.05 \\
g n . & \end{aligned}$ & $\begin{array}{r}t=65 \\
\operatorname{Insi}\end{array}$ & $\begin{array}{l}P \geq \cdot 3 \\
<.25 \\
\text { gn. }\end{array}$ & \multicolumn{2}{|c|}{ 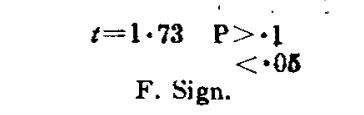 } \\
\hline
\end{tabular}

amino acid content. However the hind-brain and mid-brain do not exhibit a significant difference.

\section{DisCussion}

The foregoing results show that there is a marked deciease in the magnesium content of the different parts of the brain as a result of hypophysectomy. This may partly be due to the systemic ionic imbalance known

Acad.-B 3 
TABLE III

The biochemical contents as compared between the different parts of the brain of the hypophysectomised frog

\begin{tabular}{|c|c|c|c|c|c|c|}
\hline & Mid-brain & Fore-brain & Hind-brain & Mid-brain & Ilind-brain & Fore-brain \\
\hline \multirow{3}{*}{ Amiro acids $\mu g m / M g$} & $2.52 \pm 0.14$ & $\mathrm{~J} \cdot 7 \pm 0.25$ & $2.92 \pm 0.27$ & $2.62 \pm 0.14$ & $2.92 \pm 0.27$ & $1.7 \pm 0.25$ \\
\hline & \multicolumn{2}{|c|}{$\begin{array}{rl}t=2.08 & \mathrm{P} \\
\text { Sign. } & <.05 \\
& \end{array}$} & \multicolumn{2}{|c|}{$\begin{array}{c}t=0.96 \quad p:-2 \\
\text { Insign. }\end{array}$} & \multicolumn{2}{|c|}{$\begin{array}{c}t=2.4 \quad \mathrm{P}=025 \\
\text { Sign. }\end{array}$} \\
\hline & Mid brain & Fore-brain & Mid-brain & Hind-brain & Fore-brain & Hind-brain \\
\hline \multirow[b]{2}{*}{ RNA $\mu \mathrm{gm} / \mathrm{Mg}$} & $46 \cdot 3 \pm 7 \cdot 9$ & $46 \cdot 2 \pm 3 \cdot 8$ & $46 \cdot 3 \pm 7 \cdot 9$ & $45 \cdot 9 \pm 3 \cdot 7$ & $46 \cdot 2 \pm 3 \cdot 8$ & $45 \cdot 9 \pm 8 \cdot 7$ \\
\hline & \multicolumn{2}{|c|}{$\begin{array}{c}t=0.51 \quad \mathrm{P}>.35 \\
\text { Insign. }\end{array}$} & \multicolumn{2}{|c|}{$\begin{array}{c}t=0.57 \quad \mathrm{P}>.35 \\
<.3 \\
\text { Insign. }\end{array}$} & \multicolumn{2}{|c|}{$\begin{array}{c}t=0.62 \quad \mathrm{P}>.3 \\
\quad<.25 \\
\text { Insign. }\end{array}$} \\
\hline & Mid-brain & Fore-brain & Hind-brain & Mid-brain & Hind-brain & Fore-brain \\
\hline \multirow[b]{2}{*}{ Magnesium $\mu \mathrm{gm} / \mathrm{Gm}$} & $15 \pm 5 \cdot 2$ & $12 \pm 10 \cdot 6$ & $18 \pm 6.07$ & $15 \pm 5.2$ & $19 \pm 6 \cdot 1$ & i2 $\pm 10 \cdot 6$ \\
\hline & \multicolumn{2}{|c|}{$\begin{array}{c}t=0.53 \quad \mathrm{P}>.35 \\
\text { Insign. }\end{array}$} & \multicolumn{2}{|c|}{$\begin{array}{c}t=0.94 \quad P>.2 \\
\text { Insign. }\end{array}$} & \multicolumn{2}{|c|}{$\begin{array}{c}t=0.64 \quad \mathrm{P}>.3 \\
<.25 \\
\text { lnsign. }\end{array}$} \\
\hline & Fore-brain & Mid-brain & Mid-brain & Hind.brain & Fore-brain & Hind-brain \\
\hline \multirow[b]{2}{*}{$A^{C} \mathrm{hE} U_{\text {nit }} / \mathrm{Mg}$ protein } & $5 \cdot 02 \pm \quad \cdot 52$ & $4.67 \pm \quad \cdot 78$ & $4 \cdot 67 \pm \quad \cdot 78$ & $4 \cdot 06 \pm \quad \cdot 47$ & $5 \cdot 02 \pm \quad 62$ & $4-06 \pm \quad \cdot 47$ \\
\hline & $\begin{aligned} & t= 75 \\
& \text { Insig }\end{aligned}$ & $\begin{array}{l}P>\cdot 26 \\
<\cdot 2 \\
\text { gn. }\end{array}$ & $t=1 \cdot 3$ & $\begin{array}{l}P>-15 \\
\text { gn. }\end{array}$ & $\begin{array}{r}t=2 \cdot 07 \\
\mathrm{Sig}\end{array}$ & $\begin{array}{l}\mathrm{P}>.025 \\
<\cdot 01 \\
\text { n. }\end{array}$ \\
\hline
\end{tabular}

to occur in many vertebrates after hypophysectomy as a 1, sult of the imbalance caused in the mechanisms of water balance. The fact that the decrease noticed is greatest in the mid-brain is likely to be due to the fact that the hypophysis is removed from this region, while for normal control values the hypophysis is included in these estimations.

l.ikewise the very marked reduction in the Amino acid content in all parts of the brain after hypophysectomy may primarily be due to general 
reduction in the protein metabolism. Part of the causating mechanisms may be systemic. However, the magnitude of the change noticed is such that it cannot be entirely due to systemic causes. It appears therefore that the hormonal imbalance caused by the removal of the hypophysis may be the direct causating factor. This appears to be likely especially in view of the fact that the different parts of the CNS reacted in different degrees; thus for example, the decrease is most marked in the fore-brain. It has earlier been shown (Gomez et al., 1967) that early post-natal deprivation of thyroid hormone results in a decreased aerobic conversion of labelled glucose into amino acids (particularly aspartic) in the cerebral cortex of rat.

It is very noteworthy that the RNA content shows a remarkable decrease in all parts of the brain as a result of hypophysectomy. This may be a reflection of the diminished activity of the synthetic machinery. It is known that imbalances in thyroid function cause significant changes in protein synthesis. It is also known that increased levels of growth hormone (GH) result in neuronal hyperplasia and also cause improvement in certain kinds of behaviour such as learning capacity in rats (Block and Essman, 1965). Therefore the fact that there is a remarkable decrease in RNA in the brain of frog as a result of hypophysectomy may indicate that the drop in hormonal function has directly effected adversely the RNA and protein synthetic machinery in the CNS. This may in fact be augmented by the considerable decrease in magnesium levels, since it is known that the incorporation of amino acids into cerebral ribonucleoproteins is markedly dependent on the levels of $\mathrm{Mg}^{++}, \mathrm{K}^{+}$and $\mathrm{Na}^{+}$in the medium (Roberts and Zomzely, 1966).

However, the acetylcholine esterase content in the brain does not exhibit an equally marked alteration as a result of hypophysectomy although there is a certain decrease in its level. It is quite possible that this decrease is only a reflection of the decrease in the hormone dependent synthetic processes and may not be due to specific action of any hormone resulting from the imbalance caused due to hypophysectomy.

\section{SUMMARY}

1. The free amino acid content, magnesium, RNA and acetylcholine esterase levels in the fore-, mid-and hind-brain of normal and hypophysectomised frogs, Rana cyanophlyctus were estimated.

2. Within a week after hypophysectomy the free amino acids and magnesium show a marked decrease, which is most conspicuous in the 
fore-brain. RNA also shows a significant decrease in all the three parts of the brain although the decrease is not as marked as in $a \ldots a$ and $\mathrm{Mg}$.

3. Although acetylcholine esterase shows some decrease, this is neither conspicuous nor very significant.

4. It is suggested that decrease in $\mathrm{Mg}$ is the result of the general systemic ionic imbalance caused by the alterations in water balance caused by hypophysectomy.

5. The decrease in RNA and amino-acid levels perhaps reffects the reduction in protein synthesis. This may be a direct result of hypophysectomy and partly due to the imbalance in thyroid function resulting from hypophysectomy.

\section{REFERENCES}

1. Balazs, R., Kovacs, S., Teichgraber, P., Cocks, W. and Eayrs, J. T.

2. Block, J. B. and Essman, W. B.

J. Neurochemistry, 1968, 15, 1335-49.

3. Folin and Danielson

Nature (London), 1965, 205, 1136-37.

4. Garcia Argiz, C. A. Pasquini, J. M., Kaplan, B. and Gomez, C. T.

5. Geel, S. E. and Timiras, Ibid., 1967, 4, 135-42. P. S.

6. Gomez, C. J. and J. Neurochemistry, 1967, 14, 551-54. Ramirez de Gugliclmone, A. E.

7. Hamburgh, $M$. and Flexner, L. B.

8. Hestrin, $\mathrm{S}$.

As cited in Hawk's Physiological Chemistry, Ed. B. L. Oser, Pub. McGraw-Hill, New York, 1933.

Brain Research, 1967, 6, 621-46.

9. Kollros, J. J.

. J. Biol. Chem., 1949, 180, 249.

.. In Growth of the Nervous System, Published by Little Brown \& Co., Boston, U.S.A., 1968, pp. 179-99.

10. Milton, R, F. and Waters, W. A.

.. Methods of Quantitative Analysis, W. A. Edward Arnold \& Co., 1949.

11. Roberts, S. and Zomzcly, C. E.

In Protides of the Biological Fluids, Elsevier Publishing Co., New York, 1966, 13, 91-102.

12. Schmid-Schneider

As cited by Glick in Methods of Biochemical Analysis, Interscience Publishers, New York, 1946, 1 (1957), 
13. Timiras, P. S., Vernadakis A. and Sherwood, N. M.

14. Turner, C. D.

15. Valcana, $T$. and Timiras, P. S.

16. Vernadakis, A. and Timiras, P.S.

17. Woodbury, D. M. and Vernadakis, A.

18. Woolley, D. E., Holinka, C. F. and Timiras, P.S.

19. Zamenhof, S., Mosley, J. Science, 1966, 152, 1396-97. and Schuller, E.
In Biology of Gestation, Academic Press, New York, $1968,2,216-319$.

.. General Endocrinology, Saunders and Co., Philadelphia, U.S.A., 1966.

J. Neuochemistry, 1969, 16, 935-43.

In "Proceedings of the Second Int. Congress on Hormonal Steroids," Excerpta Medica International Congress Series, 1966, 125, 84.

In Methods in Hormone Research, Academic Press, New York, 1966, 5, 1-57.

J. Endocrinology, 1969, 84, 157-61. 